\title{
DAMPAK PANDEMI COVID-19 TERHADAP KONDISI SOSIAL EKONOMI PEDAGANG KELILING DI KELURAHAN KEDURUS KOTA SURABAYA
}

\begin{abstract}
Agus Sutedjo, Sri Murtini
Program Studi Pendidikan Geografi, Fakultas Ilmu sosial dan Hukum, UNESA

Abstrak : Pedagang keliling merupakan pekerjaan di sektor informal, menjajakan dagangannya kepada rumah tangga di perumahan. Pada saat pandemi Covid-19, aktivitas mereka tidak sesuai dengan aturan selama PSBB. Penelitian ini bertujuan mengetahui: 1) perubahan modal dan pendapatan yang diperoleh, 2) perubahan aktivitas ekonomi pedagang keliling di Kelurahan Kedurus. Sebanyak 30 pedagang keliling di Kelurahan Kedurus digunakan sebagai sampel penelitian. Data yang meliputi umur, jenis kelamin, tingkat pendidikan, modal, pemasukan, jalur keliling, cara berinteraksi dengan pembeli yang dilakukan sebelum dan saat terjadi pandemi, melalui wawancara terstruktur dan observasi. Selanjutnya data dianalisis dengan cara deskriptif kuantitatif. Modal dan pendapatan pedagang keliling di Kelurahan Kedurus pada saat pandemi mengalami penurunan dibanding sebelum pandemi, karena tidak termotivasi untuk meningkatkan produktivitasnya. Interaksi pedagang keliling dengan pembeli tidak berubah dan mereka tidak melakukan antisipasi untuk mengatasi perubahan situasi yang terjadi. Jam kerja, lama kerja dan lokasi dan jalur keliling tidak mengalami perubahan sehingga tidak dapat mempertahankan jumlah pembeli.

Kata Kunci: pendapatan, interaksi, jalur keliling, pedagang keliling
\end{abstract}

Abstract: Traveling trader is a job in the informal sector, selling his wares to households in housing. At the time of the Covid-19 pandemic, their activities were not in accordance with the rules during the PSBB. The research aims are 1) changes in capital and income earned, 2) changes in the economic activity of peddlers in Kelurahan Kedurus. A total of 30 peddlers in Kelurahan Kedurus were used as research samples. The data required includes age, gender, level of education, capital, income, circuit, how to interact with buyers before and during a pandemic, which is obtained by means of structured interviews and observations. Furthermore, the data were analyzed using quantitative descriptive. During the pandemic, the capital and income of peddlers in Kelurahan Kedurus decreased compared to before the pandemic, because they were not motivated to increase their productivity. The interaction between mobile traders and buyers has not changed and they do not anticipate to cope with the changing situation. Hours of work, length of work and location and circuit did not change so that it was unable to maintain the number of buyers.

Keywords: income, interaction, circuit, peddlers

\section{A. PENDAhuluan}

Kondisi sosial ekonomi adalah keadaan atau kedudukan seseorang dalam masyarakat sekelilingnya (Rosyid and Rudiarto, 2014) memberikan batasan tentang kondisi sosial ekonomi yaitu, merupakan suatu kedudukan yang diatur secara sosial dan menempatkan seseorang pada posisi tertentu dalam sosial masyarakat. Kondisi sosial ekonomi masyarakat ditandai adanya saling kenal mengenal antar satu dengan 
yang lain, paguyuban, sifat kegotongroyongan dan kekeluargaan.

$$
\text { Rizqyana Budi }
$$

menjelaskan kondisi sosial ekonomi sebagai kaitan antara status sosial dan kebiasaan hidup sehari-hari yang telah membudaya bagi individu atau kelompok di mana kebiasaan hidup yang membudaya ini biasanya disebut dengan culture activity. Dalam masyarakat yang sederhana maupun yang kompleks, pola interaksi atau pergaulan hidup antara individu menunjuk pada perbedaan kedudukan dan derajat atau kriteria dalam membedakan status. Pada masyarakat kecil biasanya sangat sederhana, karena disamping jumlah warganya yang relatif sedikit, juga orangorang yang dianggap tinggi statusnya tidak begitu banyak jumlah maupun ragamnya.

Basrowi and Juariyah (2010) menjelaskan bahwa kondisi sosial masyarakat mempunyai lima indikator yaitu: umur dan kelamin, pekerjaan, prestise, famili atau kelompok rumah tangga, dan keanggotaan dalam kelompok perserikatan. Indikator umur dan kelamin tidak terpengaruh oleh proses pendidikan, sehingga tinggal empat indikator yang perlu diukur tingkat perbaikannya, guna mengetahui tingginya manfaat sosial bagi masyarakat. Manfaat dalam konteks sosial ekonomi bagi masyarakat dari suatu program pendidikan adalah berupa

perbaikan dalam hal penghasilan, produktivitas, kesehatan, nutrisi, kehidupan keluarga, kebudayaan, rekreasi, dan partisipasi masyarakat.

Berbagai macam cara dapat dilakukan untuk perbaikan penghasilan maupun produktivitas pekerja, diantaranya penggunaan teknologi. Pekerja sektor informal yang sudah ada seperti pedagang kaki lima, pemilik warung (makanan, kelontong), juga memanfaatkan kemajuan teknologi informasi. Mereka sekarang juga menerima pesanan secara online dengan memanfaatkan aplikasi WhatsApp (WA), dan mengirimkan pesanan menggunakan ojek on line. Pesatnya perkembangan teknologi informasi yang ditandai dengan pemakaian internet (IT) dimana-mana, sektor informal juga akan semakin berkembang (Dewi, Listyowati, dan Napitupulu, 2020).

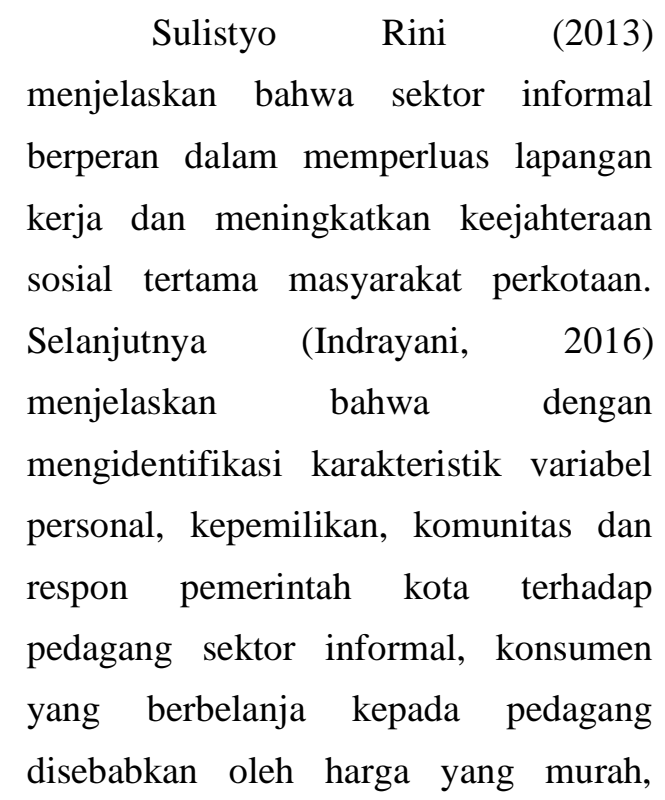

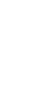


mudah ditemukan pada setiap lokasi utama lingkungan perkotaan.

Potensi tersembunyi yang dimiliki sektor informal di perkotaan dalam menopang sistem dan struktur ekonomi maupun sosial tidak dapat dipungkiri lagi. Ironisnya, dibalik konstribusinya yang begitu besar, nasib pelaku ekonomi sektor informal tidak kunjung membaik. Akses mereka terputus hubungannya dengan sistem ekonomi formal. Pemodalan masih menjadi kendala klasik akibat tidak adanya dasar hukum atas aset yang mereka miliki. Formalisasi dan legalisasi membutuhkan dukungan tataruang yang diyakini dapat mendorong produksi, memacu efisiensi, dan meningkatkan daya saing mereka. Pada gilirannya dapat meningkatkan keuntungan serta kesejahteraan kota secara keseluruhan (Alisjahbana, 2006).

Sektor informal perkotaan adalah mereka para pekerja di sektor informal yang berada di wilayah perkotaan. Mereka sebagian besar para pendatang di kota, terpengaruh oleh rekan sedesanya yang lebih dahulu sukses, disamping karena langkanya lapangan kerja dan kehidupan di perdesaan. Semakin sempitnya lahan pertanian di pedesaan, suksesnya program pendidikan dasar, pesatnya pembangunan di kota-kota dengan munculnya banyak industri telah mendorong terjadinya urbanisasi secara besar-besaran (Wauran, 2012).

Salah satu jenis usaha yang termasuk sektor informal adalah pedagang keliling. Berbagai barang didistribusikan secara berkeliling untuk dijual kepada orang yang memerlukan. Pada umumnya motivasi pedagang adalah memperoleh penghasilan yang cukup untuk sekedar mempertahankan hidup dengan bekerja tanpa mengenal waktu. Pedagang keliling menjajakan dagangannya untuk melayani kebutuhan hidup, terutama makanan kepada rumah tangga di kampung-kampung atau perumahan. Pedagang keliling sepenuhnya menggantungkan dari penghasilan yang didapatkan pada hari itu juga dari hasil jualannya. Pada saat pandemi ini, sebenarnya aktivitas keliling kampung tidak sesuai dengan aturan yang diterapkan selama PSBB. Namun jika tidak berjualan, mereka tidak mendapat penghasilan sehingga bisa mengganggu kehidupan keluarganya. Hal ini merupakan permasalahan yang dihadapi mereka.

Pedagang keliling di Kelurahan Kedurus, Kota Surabaya terdiri dari banyak jenis pedagang, yaitu pedagang bakso, roti (bak pao, sari roti, donat), sate, minuman (es, dhawet), sayuran, buah-buahan, mie dan nasi goreng, puthu, semanggi, daging. Keberadaan mereka di kampung dan perumahan dari pagi sampai malam, namun ada jadwal 
tertentu bagi pedagang untuk berjualan berkeliling, misalnya pedagang sayur pada pagi hari sedangkan mie/nasi goreng kebanyakan sore sampai malam hari. Pada masa pandemi Covid-19 ini sebagian besar menggunakan masker dalam melayani pembeli dan mereka msih tetap berjualan untuk bertahan hidup meskipun situasi kurang mendukung.

Modal yang mendukung pedagang keliling akan meningkatkan produktivitas mereka. Peningkatan produktivitas akan menaikkan penghasilan dan kondsi sosial ekonominya. Hal yang sama dapat terjadi apabila mampu mengefisiensikan waktu dan perjalanan keliling mereka.

Berdasarkan latar belakang permasalahan yang diuraikan seperti di atas, maka tujuan penelitiannya adalah :

1. Mengetahui perubahan modal dan jumlah pendapatan sebelum dan saat pandemi Covid 19 para pedagang keliling di Kelurahan Kedurus Kota Surabaya.

2. Mengetahui perubahan aktivitas ekonomi, meliputi perubahan pola interaksi, waktu berjualan dan lokasi berjualan para pedagang keliling di Kelurahan Kedurus Kota Surabaya

\section{B. METODE}

Lokasi penelitian dilakukan di wilayah Kelurahan Kedurus, Kecamatan Karangpilang, Kota Surabya. Lokasi ini merupakan permukiman padat terdiri dari perkampungan dan kompleks perumahan. Kelurahan Kedurus terletak di bagian selatan Kota Surabaya, dekat dengan perbatasan Kota Surabaya dan Kabupaten Sidoarjo serta di pinggir jalan utama menuju luar kota. Di dalam wilayah Kelurahan Kedurus juga terdapat pasar tradisional yang cukup besar dan ramai yang buka dari pagi sampai siang.

Populasi dalam penelitian ini adalah pedagang keliling yang beroperasi di dalam wilayah Kelurahan Kedurus dan sekitarnya. Pedagang keliling meliputi pedagang sayur, makanan dan minuman. Pedagang keliling dibatasi pada pedagang yang menjajakan dagangannya di wilayah Kelurahan Kedurus dan sekitarnya. Sebanyak 30 pedagang keliling diambil sebagai sampel penelitian meliputi pedagang makanan, pedagang minuman, pedagang sayur, dan pedagang buah.

Pengambilan data dilakukan dengan wawancara terstruktur dengan bantuan pedoman wawancara dan observasi. Wawancara terstruktur dilakukan untuk mendapatkan data penghasilan rata-rata selama sebulan sebelum dan saat terjadi pandemi Covid19 , ada tidaknya perubahan lokasi, jalur perjalanan keliling, waktu berjualan, jumlah hari kerja setiap minggu, dan pola interaksi antara pedagang dengan pembeli. Observasi dilakukan untuk mengetahui jalur jalan yang ditempuh 
pedagang keliling dan barang-barang yang dijual. Wawancara dilakukan di depan rumah pembeli setelah terjadi transaksi atau di tempat pemberhentian pedagang keliling dalam menawarkan dagangannya.

Data hasil penelitian dianalisis secara deskriptif untuk mengetahui ada tidaknya perubahan jumlah modal, pendapatan, jalur dan lokasi penjualan, waktu berjualan, dan pola interaksi dengan pembeli pada waktu sebelum dan pada saat pandemi covid 19. Perubahan jumlah penggunaan modal, pendapatan, jalur perjalanan, dan lokasi berjualan diketahui dengan membandingkan saat sebelum terjadi pandemi covid-19 dengan saat terjadi pandemi covid-19. Perubahan dikatakan positip/naik apabila nilai pada sebelum pandemi covid-19 lebih kecil daripada saat terjadi pandemi, dan dikatakan negatip/turun apabila nilai pada sebelum pandemi covid-19 lebih besar daripada saat terjadi pandemi, dikatakan tidak ada perubahan apabila sebelum dengan saat terjadi pandemi covid-19 mempunyai nilai yang sama.

\section{HASIL DAN PEMBAHASAN}

\section{C.1. HASIL}

Dibandingkan dengan sebelum pandemi covid-19, pendapatan pedagang keliling di Kelurahan Kedurus pada saat masih terjadi pendemi mengalami penurunan. Penurunan pendapatan ratarata sebesar Rp 20.000,- perhari atau 15
$\%$. Penurunan sebesar itu cukup berarti pengaruhnya bagi pedagang keliling.

Dibandingkan sebelum pandemi, selama terjadi pandemi covid-19, jumlah konsumen pedagang keliling di Kelurahan Kedurus baik pembeli tidak tetap maupun pembeli tetap mengalami penurunan. Rata-rata penurunan pembeli sebesar $16 \%$ dengan penurunan pembeli tetap lebih besar penurunannya. Hal sebaliknya terjadi pada pedagang sayur keliling yang mengalami peningkatan pelanggan.

Modal yang digunakan para pedagang keliling di Kelurahan Kedurus merupakan modal sendiri. Modal yang digunakan relatif kecil yakni sebesar Rp 299.000 setiap hari. Pada waktu pandemi Covid-19 modal yang digunakan mengalami peturunan sebesar Rp75.000atau sebesar $25 \%$.

Lama bekerja yang dilakukan oleh pedagang keliling di Kelurahan Kedurus, sekitar 5 jam, 8 jam atau 11 jam setiap hari. Lama/durasi jam kerja yang bervariasi ini tidak berkaitan dengan besar kecilnya pendapatan. Bakerja dalam durasi waktu yang berbeda, penghasilan pedagang keliling tidak jauh berbeda. Pekerjaan keliling dilakukan pada pagi, siang, sore atau malam hari.

Pedagang keliling di Kelurahan Kedurus sebagaian besar bekerja selama 7 hari setiap minggunya, baik pada waktu pandemi maupun sebelum pandemi. Berarti para pedagang keliling tidak 
mengenal hari libur untuk istirahat, kondisi seperti ini sebenarnya membahayakan kesehatan mereka. Pada aspek lain, jam kerja setiap hari sebagian besar pedagang keliling kurang lebih 5 jam setiap hari, hal ini berarti bahwa pedagang keliling setiap harinya telah beristirahat cukup untuk menyegarkan kembali fisik dan pikirannya, sehingga dapat melakukan kegiatannya selama seminggu penuh tanpa hari libur.

Interaksi yang terjadi antara pembeli dengan pedagang keliling di Kelurahan Kedurus yakni berkomunikasi secara langsung. Penggunaan sarana komunikasi modern, seperti Hand Phone tidak digunakan. Bentuk komunikasi antara pedagang dengan pembeli melalui beberapa cara. Pemberitahuan kedatangan pedagang melalui suara tertentu dengan musik atau mulut, sedangkan pada saat transaksi biasanya pembeli memberikan julukan-julukan tertentu kepada pedagang, misalnya 'cak' atau 'mas' namun ada pula yang langsung menyebut namanya.

Pedagang keliling menentukan lokasi usaha dengan cara menetapkan jalur perjalanan dan tempat pemberhentian yang tetap. Selama pandemi sebagaian besar pedagang keliling di Kelurahan Kedurus tidak melakukan perubahan jalur sedangkan pedagang yang melakukan perubahan jalur hanya mengalami perubahan jalur relatif kecil dibandingkan saat sebelum pandemi..

\section{C.2. PEMBAHASAN}

Faktor yang berpengaruh terhadap penurunan pendapatan antara lain situasi perdagangan yang mengalami perubahan sehingga pedagang keliling harus melakukan penyesuaian. Situasi ini berkaitan dengan kondisi pembeli yang berubah pula, baik orangnya maupun kondisi ekonomi pembeli. Hal ini tidak jauh berbeda dengan hasil penelitian (Andiny and Kurniawan 2017) bahwa situasi baru akan memerlukan penyesuaian bagi pedagang, sehingga untuk sementara mengalami penurunan pendapatan.

Pada umumnya selama terjadi pandemi jumlah konsumen pedagang keliling di Kelurahan Kedurus baik pembeli tidak tetap maupun pembeli tetap mengalami penurunan. Hal itu berkibat pada penurunan jumlah barang yang dijual, dampak lebih lanjut adalah penurunan pendapatan selama masa pandemi. Penelitian Herispon (2020) juga menunjukkan bahwa akibat dari jumlah konsumen yg menurun, pedagang mengurangi jumlah barang yang dibeli untuk dijulal lagi, yang berdampak pada berkurangnya jumlah pendapatan pedagang.

Faktor lain yang berdampak pada penurunan pendapatan adalah modal yang digunakan. Pada masa pandemi Covid-19, pedagang keliling di 
Kelurahan Kedurus mengalami penurunan jumlah modal. Penurunan jumlah modal tersebut berdampak pada jumlah barang yang dibeli dan akan dijual lagi mengalami penurunan, atau bahan-bahan mentah yang dibeli dan selanjutnya diolah untuk dijual juga mengalami penurunn. Penurunan jumlah penjualan akan menurunkan jumlah pendapatan. Penelitian yang dilakukan oleh Wulandari (2018) menunjukkan bahwa modal merupakan faktor yang berpengaruh secara signifikan terhadap pendapatan yang diperoleh pedagang.

Kecilnya modal mengakibatkan volume barang yang akan dijual lagi dalam jumlah kecil, kondisi demikian juga akan memperkecil pendapatan yang diperoleh. Sehubungan dengan menurunnya jumlah modal yang digunakan oleh pedagang keliling di Kelurahan Kedurus maka pendapatan mereka juga semakin kecil. Kondisi tersebut selaras dengan hasil penelitian Yuniarti (2019) bahwa besar kecilnya modal yang digunakan akan berpengaruh terhadap penghasilan, makin kecil modal makin kecil pendapatan. Handoyo (2017) juga mengatakan bahwa pedagang keliling termasuk sektor informal yang berpendapatan kecil karena barangbarang yang dijual relatif tidak banyak dan barang-barang yang dijual bukan barang-barang mahal.

Durasi bekerja yang dilakukan pedagang keliling di Kelurahan Kedurus setiap harinya tidak berpengaruh. Hal ini tidak jauh berbeda dengan pendapat Farras Hadyan and Saftarina (2017) bahwa lamanya seseorang bekerja yang optimal dalam sehari pada umumnya 6-8 jam, lebih dari itu akan terjadi penurunan produktivitas, kecelakaan kerja atau penyakit akibat kerja.

Durasi kerja yang relatif pendek oleh pedagang keliling di Kelurahan Kedurus berdampak pada kecilnya pendapatan. Penelitian yang dilakukan oleh Wulandari (2018) dan Yuniarti (2019) juga menyatakan hal serupa, yakni jam kerja dan lama usaha berpengaruh secara signifikan terhadap pendapatan pedagang keliling.

Jumlah hari kerja selama 7 hari seminggu yang dilakukan oleh sebagian pedagang keliling di Kelurahan Kedurus tidak menyebabkan kelelahan. Hal ini berbeda dengan pendapat Farras Hadyan dan Saftarina (2017) bahwa jumlah hari kerja yang berlebihan dapat menyebabkan kelelahan kerja yaitu suatu kondisi yang timbul pada setiap individu yang tidak sanggup lagi untuk melakukan aktivitasnya yang akhirnya akan menurunkan produktivitas

Simbol-simbol tertentu dignakan untuk memperlancar komunikasi atau interaksi antara pedagang keliling dengan pembeli. Hal itu selaras dengan hasil penelitian Muzdalifah, Sukidin, dan Suharso (2019), Bertharia (2018) dan Prasinata 
Panggabean (2017) bahwa dalam berkomunikasi antara pedagang dan pembeli, pedagang diberi simbol-simbol tertentu oleh pembeli seperti julukan tertentu, sementara pedagang memberikan suara-suara tertentu melalui mulutnya atau alat tertentu.

Jalur lokasi pedagang keliling di Kelurahan Kedurus tidak mengalami perubahan, kondisi demikian berdampak pada pendapatan pedagang keliling di Kelurahan Kedurus yang mengalami penurunan pendapatan. Hal ini tidak jauh berbeda dengan pendapat Hastin and Gusmadi (2015) bahwa salah satu faktor yang berpengaruh terhadap pendapatan bakso keliling adalah lokasi berjualan. Prihatminingtyas (2019) juga menjelaskan bahwa lokasi berpengaruh terhadap pendapatan pedagang informal/tradisional, penentuan lokasi usaha sangat penting agar usahanya beroperasi secara efisien dan mencapai pendapatan yang diinginkan.

\section{KESIMPULAN}

Berdasarkan hasil penelitian dan pembahasan seperti diuraikan di atas maka dapat ditarik kesimpulan seperti berikut.

a. Pendapatan pedagang keliling di Kelurahan Kedurus pada saat pandemi covid-19 mengalami penurunan dibandingkan dengan sebelum pandemi. Faktor-faktor yang mempengaruhi penurunan pendapatan adalah :
- Jumlah pembeli dan pelanggan menurun.

- Jumlah modal yang digunakan kecil dan mengalami penurunan sehingga barang dagangan yang dijual berkurang.

- Sebagian besar pedagang keliling kurang termotivasi untuk meningkatkan produktivitasnya

b. Aktivitas ekonomi pedagang keliling di Kelurahan Kedurus yang terjadi pada sebelum pandemi dibandingkan saat terjadi pandemi adalah seperti berikut.

- Bentuk interaksi antara pedagang keliling dengan pembeli tidak mengalami perubahan yakni menggunakan komunikasi langsung.

- Pada saat pandemi jumlah pembeli atau pelanggan mengalami penurunan, namun pedagang tidak melakukan antisipasi untuk mengurangi dampak terjadinya penurunan jumlah pelanggan.

- Waktu kerja pedagang keliling tidak banyak mengalami perubahan, yakni sebagian besar melakukannya pada pagi dan siang hari.

- Lama bekerja setiap minggunya tidak banyak mengalami perubahan, namun terdapat sebagian pedagang keliling yang mengalami penurunan, besarnya penurunan hanya sehari perminggu selama pandemi.

- Jalur keliling pedagang sebagian besar tidak mengalami perubahan, sebagian 
kecil pedagang yang mengubah jalur perjalananannya hanya terbatas pada sedikit penambahan jarak dan jam kerja.

\section{DAFTAR PUSTAKA}

Alisjahbana. 2006. "Memberdayakan Sektor Informal: Dari Legalisasi Aset Hingga Dukungan Tata Ruang." doi: https://dx.doi.org/10.12962/j2716179 X.v1i2.2340.

Andiny, Puti, and Agus Kurniawan. 2017. "Analisis Pendapatan Pedagang Kaki Lima Sebelum Dan Sesudah Program Relokasi Di Kota Langsa." Jurnal Samudra Ekonomika 1(2):196.

Basrowi, Siti, and Juariyah. 2010. "Aablisis Kondisi Sosia Ekonomi Dan Tingkat Pendidikan Masyarakat Desa Srigading, Kecamatan Labuhan Maringgai, Kabupaten Lampung Timur." Jurnal Ekonomi \& Pendidikan 7(April):58-81.

Bertharia, S. .. 2018. "Simbol Komunikasi Pedagang Keliling Di Sidosermo Surabaya. Surabaya, FISIP Untag Surabaya."

Dewi, Sita, Dwi Listyowati, and Bertha Elvy Napitupulu. 2020. "Sektor Infromal Dan Kemajuan Teknologi Infromasi Di Indonesia." Jurnal Mitra Manajemen 11(1):29-38.

Farras Hadyan, Muhammad, and Fitria Saftarina. 2017. "Hubungan Usia, Lama Kerja, Masa Kerja Dan Indeks Massa Tubuh (IMT) Terhadap Kejadian Low Back Pain (LBP) Pada Petani Di Desa Munca Kabupaten Pesawaran." Medula 7(4):141-46.

Handoyo, Eko. 2017. "Modal Sosial Dan Kontribusi Ekonomi Pedagang Sayur
Keliling Di Semarang." 39(2).

Hastin, Mira, and Ijal Gusmadi. 2015. "Analisis Produktifitas Kewirausahaan Pedagang Bakso Keliling Dalam Meningkatkan Pendapatan Keluarga (Studi Kasus Di Kecamatan Siulak)." 2015:1-239.

Herispon, Herispon. 2020. "Dampak Ekonomi Pembatasan Sosial Berskala Besar Terhadap Masyarakat Kota Pekanbaru Di Provinsi Riau." Eko Dan Bisnis: Riau Economic and Business Review 11(2):164-73.

Indrayani, Henni. 2016. "Pengembangan Dan Pemberdayaan Sektor Informal Di Kota Pekanbaru." Jurnal AlIqtishad. Vol: 12 No: 2, 2016.

Muzdalifah, Siti, Sukidin Sukidin, and Pudjo Suharso. 2019. "Karakteristik Pedagang Tradisional Di Pasar Kepatihan Kabupaten Jember.” Junal Pendidikan Ekonomi: Jurnal Ilmiah Ilmu Pendidikan, Ilmu Ekonomi Dan Ilmu Sosial 13(1):94. doi: 10.19184/jpe.v13i1.10426.

Prasinata Panggabean, Amestia. 2017. "Kualitas Interaksi Sosial Antara Penjual Dan Pembeli Di Taman Pintar Book Store Yogyakarta." doi: https://doi.org/10.23917/indigenous.v $2 \mathrm{i} 2.4460$.

Prihatminingtyas, Budi. 2019. "Pengaruh Modal, Lama Usaha, Jam Kerja Dan Lokasi Usaha Terhadap Pendapatan Pedagang Di Pasar Landungsari." Jurnal Ilmu Manajemen Dan Akutansi 7(2):147-54.

Rizqyana Budi, Erika. 2018. "Analisis Kondisi Sosial Ekonomi Masyarakat Terhadap Ketersediaan Sanitasi." Economics Development Analysis Journal 6(2):147-54. doi: 
10.15294/edaj.v6i2.22211.

Rosyid, M., and Iwan Rudiarto. 2014.

"Karakteristik Sosial Ekonomi

Masyarakat Petani Kecamatan Bandar

Dalam Sistem Livelihood Pedesaan.”

doi: https://doi.org/10.14710/

geoplanning.1.2.74-84.

Sulistyo Rini, Hartati. 2013. "Dilema

Keberadaan Sektor Informal."

KOMUNITAS: International Journal

of Indonesian Society and Culture

4(2):200-209. doi:

10.15294/komunitas.v4i2.2415.

Wauran, Patrick C. 2012. "Strategi

Pemberdayaan Sektor Informal

Perkotaan Di Kota Manado." Jurnal

Pembangunan Ekonomi Dan

Keuangan Daerah (PEKD) 7(3):1-

30.

Wulandari, Christi Mei. 2018. "Analisis

Pendapatan Pedagang Pasar Baru

Kencong Di Kabupaten Jember ." .

Jurnal Ilmu Ekonomi .Vol:1 No: 2, 2017:215-224

Yuniarti, Puji. 2019. "Analisis Faktor-

Faktor Yang Mempengaruhi

Pendapatan Pedagang Di Pasar

Tradisional Cinere Depok." Widya

Cipta - Jurnal Sekretari Dan

Manajemen 3(1):165-70. doi:

10.31294/widyacipta.v3i1.5296. 